\title{
ARBUSCULAR MYCORRHIZAL FUNGI IN PAPAYA PLANTATIONS OF ESPÍRITO SANTO AND BAHIA, BRAZIL
}

\author{
Aldo Vilar Trindade ${ }^{1 *}$; José Oswaldo Siqueira² ${ }^{2}$ Sidney Luiz Stürmer ${ }^{3}$ \\ ${ }^{1}$ Embrapa Mandioca e Fruticultura Tropical, Cruz das Almas, BA, Brasil; ${ }^{2}$ Universidade Federal de Lavras, Lavras, MG, Brasil; \\ ${ }^{3}$ Universidade Regional de Blumenau, Blumenau, SC, Brasil
}

Submitted: April 01, 2005; Returned to authors for corrections: March 09, 2006; Approved: May 22, 2006

\begin{abstract}
The aim of this study was to obtain knowledge on arbuscular mycorrhizal (AM) associations in papaya (Carica papaya, L.) in field soils and nursery conditions. Sixty seven soil and root samples were taken in February and May of 1996, from 47 commercial plantations in the North of Espirito Santo State and the West and South of Bahia State, in Brazil. Samples were used for direct spore counts, root colonization assessment and for trap culture with Sorghum bicolor (L.) Moench and Crotalaria juncea L. Additional sampling was done in commercial nurseries to evaluate mycorrhizal colonization. Although papaya cropping systems are usually under high input of fertilizers and pesticides, papaya roots showed considerable arbuscular mycorrhizal (AM) colonization, ranging from $6 \%$ to $83 \%$. Colonization rates were most influenced by available soil $\mathrm{P}$, correlated positively with percentage of sand and soil $\mathrm{pH}$, but correlated negatively with soil clay content. AM colonization of nursery seedlings was very low in most samples. Field spore numbers varied from 34 to 444/30g of soil. All Glomerales families were represented and 24 fungal species identified. Glomus etunicatum, Paraglomus occultum, Acaulospora scrobiculata and Gigaspora sp. were the most common species.
\end{abstract}

Key words: Glomeromycota, agroecosystems, ecology, Carica papaya

\section{INTRODUCTION}

Arbuscular mycorrhizas (AM) are associations formed by approximately 160 species (10) of fungi of the phylum Glomeromycota (22) and roots of most plant species. These fungi experienced 400 million years of coevolution with plants (19) which allowed them a generalized occurrence and distribution in agrosystems and natural ecosystems. However, the occurrence of a defined fungal species or community is rarely predictable because it is influenced by edaphic factors and plant community characteristics. In specific agrosystems, with similar edaphic and climatic characteristics, it is possible to find a pattern of AM fungi ocurrence for a defined crop (12) and for crops from different sites and ages (16). Species richness and diversity of AM fungi have been shown to be influenced by several soil factors. Siqueira et al. (24) found 33 AM fungal species during a survey on agrosystems of coffee, fruits, annual crops and ecosystems-Cerrados- in Brazil. Acaulospora species were most frequently detected in soils with $\mathrm{pH}$ of 6.5 or lower. The authors also found that certain species, such as Gigaspora margarita, reached their highest frequencies in soils with high $\mathrm{Al}^{3}$ content. Similarly, in cacao plantations and nurseries in Venezuela, Cuenca and Menezes (4) detected 15 AM fungal species in all sites surveyed and indicated that species richness and diversity were inversely correlated with available $\mathrm{P}$ in soil. AM colonization rates may vary between varieties of a same plant species, as occurred with banana (Musa spp) (7). These results suggest effect of shoots and host genetics on mycorrhizal association. Cropping systems are very complex and may cause qualitative and quantitative shifts in AM fungal

*Corresponding Author. Mailing address: Rua Embrapa s/n, Caixa Postal 007, Cruz das Almas, BA, Brasil. Tel. (+5575) 3621-8016; Fax: (+5575) 3621-8096. E-mail: aldo@cnpmf.embrapa.br 
communitites and therefore influence the overall occurrence and community structure of this group of microrganisms.

Considering the complexity of mycorrhizal systems, in particular the unpredictability of species occurrence and functionality, it is necessary to gain a better understanding of the ecology of AM fungi in sites where inoculation or management of native AM fungi populations are intended (24).

Papaya (Carica papaya L.) is a highly appreciated fruit crop widely cultivated around the world, particularly in Brazil. In the states of Espirito Santo and Bahia papaya plantations extend to an area of 35.556 ha (9) mainly as a monoculture. Under controlled conditions, papaya plants have shown high capabilities to form $\mathrm{AM}$ and to benefit from AM in fumigated (29) and unfumigated soils (27). In field conditions, Mamatha et al. (14) have observed that papaya trees respond to inoculation with efficient AM fungi reducing the need for $\mathrm{P}$ fertilization at least until the start of production. Considering the importance of AM to plant growth, reduction of fertilizer use and agrosystem sustainability, this work aimed to evaluate the occurrence of AM fungi in nursery and high-yield commercial plantations of papaya in three different regions in Brazil.

\section{MATERIALS AND METHODS}

Sixty seven soil samples were collected in February and May, 1996 from 47 papaya plantations located in the North of Espirito Santo State (Linhares and São Mateus counties), and in the West (Barreiras and Luiz Eduardo Magalhães counties) and South of Bahia State (Porto Seguro, Eunápolis and Itabela counties), Brazil. Predominant soil types were Oxisols and Ultisols in Espirito Santo and Oxisols and Entisols in West and South of Bahia. Average air temperatures ranged from $21^{\circ} \mathrm{C}$ to $26^{\circ} \mathrm{C}$ in Espirito Santo and West of Bahia, and $22^{\circ} \mathrm{C}$ to $27^{\circ} \mathrm{C}$ in the South of Bahia. Major soil characteristics are presented in Table 1. Papaya varieties differed among orchards. Most varieties (71\%) belonged to 'Solo' group (Sunrise Solo, Improved Sunrise
Solo "Line" 72/12 and Baixinho de Santa Amália) and the remaining 29\% belonged to 'Formosa' group (hybrids Tainung $\mathrm{N}^{\circ} 1$ and $\mathrm{N}^{\circ} 2$ ). Crop ages ranged from 4 months to 3 years. All (except one) sites were irrigated mainly by localized sprinkling. Conventional sprinkling and central pivot were also used. Soil fertilization and chemical control of diseases and pests were common in all orchards.

Samples were taken from homogeneous areas in terms of landscape, crop age and variety, at each site, by collecting 7 to 10 single samples consisting of $0.5 \mathrm{dm}^{3}$ of soil and roots of each plant as follows. Each single sample was composed by two sub-samples, collected in opposite positions under the plant canopy, $30-50 \mathrm{~cm}$ from the stem and 0 to $20 \mathrm{~cm}$ deep. Single samples were pooled to form one compound sample of $0.5 \mathrm{dm}^{3}$ of soil per location. Soil samples were analyzed for available $P$, $\mathrm{pH}$, organic matter and texture (Table 1) and total counts of AM fungal spores. Roots were gently separated from the soil, washed and stained with $0.05 \%$ trypan blue (17). Papaya seedlings (45 to 150 days old) were also taken from four commercial nurseries (10 seedlings/nursery) located on South of Bahia. Seedlings were raised on $0.5-1.0 \mathrm{dm}^{3}$ plastic bags with a substrate composed of $70 \%$ of sieved subsoil and $30 \%$ of manure supplemented with $\mathrm{P}$ and $\mathrm{K}, 100 \mathrm{mg} / \mathrm{kg}$ substrate, each. Both field and nursery roots were scored for AM root colonization (1).

In order to multiply native AM fungal spores for accurate identification, and to establish single isolate cultures, soil samples were used to set up trap cultures by growing Sorghum bicolor (L.) Moench and Crotalaria juncea L., together, as host plants. Trap cultures were established by disposing $0.2 \mathrm{~L}$ of sterile sand on the bottom of $1 \mathrm{~L}$ plastic pots and covering with $0.6 \mathrm{~L}$ of a mixture of native soil + sterile sand + vermiculite $(2: 1: 1, \mathrm{v}: \mathrm{v}: \mathrm{v})$. Trap plant seeds were sown over this mixture and covered with a third layer of $0.2 \mathrm{~L}$ of sterile sand. After five months, plant shoots were removed, and soil and roots were collected, air-dried and stored in a refrigerator $\left(4-10^{\circ} \mathrm{C}\right)$ until use for spore extractions and identification.

Table 1. Crop age, chemical and physical soil characteristics in papaya (Carica papaya L.) fields from three regions in Brazil.

\begin{tabular}{|c|c|c|c|c|c|c|c|c|c|}
\hline Parameter & $\begin{array}{l}\text { Age } \\
\text { (years) }\end{array}$ & $\begin{array}{c}\mathrm{P} \\
\left(\mathrm{mg} \mathrm{dm}^{-3}\right)\end{array}$ & $\mathrm{pH}$ & $\begin{array}{l}\text { Organic matter } \\
\qquad\left(\mathrm{g} \mathrm{kg}^{-1}\right)\end{array}$ & $\begin{array}{l}\text { Coarse sand } \\
\left(\mathrm{g} \mathrm{kg}^{-1}\right)\end{array}$ & $\begin{array}{l}\text { Fine sand } \\
\left(\mathrm{g} \mathrm{kg}^{-1}\right)\end{array}$ & $\begin{array}{l}\text { Total Sand } \\
\left(\mathrm{g} \mathrm{kg}^{-1}\right)\end{array}$ & $\begin{array}{c}\text { Silt } \\
\left(\mathrm{g} \mathrm{kg}^{-1}\right)\end{array}$ & $\begin{array}{c}\text { Clay } \\
\left(\mathrm{g} \mathrm{kg}^{-1}\right)\end{array}$ \\
\hline \multicolumn{10}{|c|}{ North of Espírito Santo } \\
\hline Range & $0.35-2.5$ & $7-352$ & $4.7-6.1$ & $16-31$ & $360-730$ & $150-230$ & $520-880$ & $10-180$ & $90-350$ \\
\hline Average & 0.98 & 89.7 & 5.5 & 24 & 525 & 186 & 710 & 77 & 211 \\
\hline \multicolumn{10}{|c|}{ West of Bahia } \\
\hline Range & $0.58-3$ & $18-286$ & 5.3-7.4 & $8-29$ & $150-290$ & $360-660$ & $540-810$ & $60-200$ & $80-350$ \\
\hline Average & 1.44 & 90 & 6.4 & 14.3 & 182 & 549 & 731 & 108 & 160 \\
\hline \multicolumn{10}{|c|}{ South of Bahia } \\
\hline Range & $0.58-2.5$ & $3.3-352$ & $4.5-6.5$ & $33-44$ & $460-770$ & $130-280$ & $660-930$ & $40-160$ & $20-230$ \\
\hline Average & 1.24 & 83.6 & 5.5 & 37 & 600 & 207 & 807 & 91 & 100 \\
\hline
\end{tabular}


Spores were extracted and mounted on PVLG and Melzer's reagent. Species identification was done according to Schenck and Pérez (21) and by comparison with reference culture information available in the web page (http://invam.caf.wvu.edu/ fungi/taxonomy/speciesID.htm) of the International Culture Collection of (Vesicular) Arbuscular Mycorrhizal Fungi (INVAM) (11).

After identification, the total number of species recovered ( $\mathrm{T})$ and $\mathrm{AM}$ fungal species richness $(\mathrm{R}=$ average of species number per sample) were determined. Repetition index $(\mathrm{RI}=\mathrm{R} / \mathrm{T})$ was also calculated. This index represents the estimate of the minimum number of sub-samples necessary to cover all diversity present in the group of samples. Frequency (\%) was calculated based on the occurrence of a species on trap cultures. Pearson's coefficient was used to correlate soil chemical and physical characteristics with data on spore abundance and root colonization (5).

\section{RESULTS}

Arbuscular mycorrhizal colonization of field papaya samples was highly variable between and within each cropping region (Table 2). Values ranged from almost zero up to $83 \%$ in the South of Bahia. The lowest variation occurred in the West of Bahia (10-40\%). Nursery papaya plants showed low levels of colonization, varying from 0 to $7 \%$. Under this condition, the roots of most samples (44\%) showed no evidence of AM colonization. Spore counts from field samples ranged from 34108 spores/30g of soil in the West of Bahia to 65-444 spores/ $30 \mathrm{~g}$ in the North of Espirito Santo. These two regions also had the lowest (67) and the highest (212) average of spore counts, respectively. Root colonization in samples from the North of Espirito Santo and West of Bahia showed negative correlations with soil P (Table 3). Correlation between AM colonization and soil $\mathrm{pH}$ was positive and significant only in South of Bahia.

Table 2. Arbuscular mycorrhizal colonization and spore density in rhizosphere samples from papaya (Carica papaya L.) fields in three regions in Brazil.

\begin{tabular}{lcccccc}
\hline & $\begin{array}{c}\text { North of Espírito Santo } \\
\left(\mathrm{N}^{\circ}=15\right)^{*}\end{array}$ & \multicolumn{2}{c}{$\begin{array}{c}\text { West of Bahia } \\
\left(\mathrm{N}^{\circ}=18\right)\end{array}$} & \multicolumn{2}{c}{$\begin{array}{c}\text { South of Bahia } \\
\left(\mathrm{N}^{\circ}=34\right)\end{array}$} \\
\hline Parameter & $\begin{array}{c}\text { Colonization } \\
(\%)\end{array}$ & $\begin{array}{c}\text { Spores } \\
\left(\mathrm{n}^{\circ} / 30 \mathrm{~g}\right)\end{array}$ & $\begin{array}{c}\text { Colonization } \\
(\%)\end{array}$ & $\begin{array}{c}\text { Spores } \\
\left(\mathrm{n}^{\circ} / 30 \mathrm{~g}\right)\end{array}$ & $\begin{array}{c}\text { Colonization } \\
(\%)\end{array}$ & $\begin{array}{c}\text { Spores } \\
\left(\mathrm{n}^{\circ} / 30 \mathrm{~g}\right)\end{array}$ \\
\hline Range & $6-53$ & $65-444$ & $10-40$ & $34-108$ & $1-83$ & $43-325$ \\
Average & 33 & 212 & 23 & 67 & 38 & 168 \\
\hline
\end{tabular}

* Number of analysed samples in each region.

Table 3. Correlation between arbuscular mycorrhiza colonization, spores density and soil chemical and physical characteristics in papaya crops (Carica papaya L.), in three regions in Brazil ${ }^{1 / 2 /}$.

\begin{tabular}{|c|c|c|c|c|c|c|c|c|}
\hline Characteristics & $\mathrm{P}$ & $\mathrm{pH}$ & Organic matter & Coarse sand & Fine sand & Total sand & Silt & Clay \\
\hline \multicolumn{9}{|c|}{ North of Espírito Santo (15) } \\
\hline Colonization & $-0.74^{* *}$ & 0.02 & -0.11 & $0.60^{* *}$ & -0.07 & $0.56^{*}$ & -0.33 & -0.60 ** \\
\hline Spore density & 0.04 & -0.06 & 0.11 & -0.25 & -0.23 & -0.30 & 0.27 & 0.28 \\
\hline \multicolumn{9}{|c|}{ West of Bahia (18) } \\
\hline Colonization & $-0.45^{*}$ & 0.00 & 0.21 & 0.06 & -0.40 & -0.36 & $0.43^{*}$ & 0.24 \\
\hline Spore density & -0.37 & -0.10 & $0.54^{*}$ & 0.05 & $-0.57^{* *}$ & $-0.52^{*}$ & 0.16 & $0.60^{* *}$ \\
\hline \multicolumn{9}{|c|}{ South of Bahia (34) } \\
\hline Colonization & 0.00 & $0.46^{* *}$ & -0.09 & 0.05 & 0.12 & 0.12 & -0.09 & -0.11 \\
\hline Spore density & -0.14 & -0.22 & -0.25 & $0.34^{*}$ & -0.22 & 0.27 & -0.25 & -0.23 \\
\hline \multicolumn{9}{|c|}{ All regions (67) } \\
\hline Colonization & -0.18 & 0.00 & $0.32^{* *}$ & $0.40^{* *}$ & $-0.35^{* *}$ & $0.22^{*}$ & -0.10 & $-0.22 *$ \\
\hline Spore density & -0.07 & $-0.44^{* *}$ & $0.34^{* *}$ & $0.50^{* *}$ & $-0.60^{* *}$ & -0.02 & -0.16 & 0.09 \\
\hline
\end{tabular}

${ }^{1 /}$ Values in parenthesis represent number of samples in each region;

$2 / *$ and $* *$ represent correlation coefficients of Pearson significant at $p<0.05$ and $p<0.01$, respectively. 
When all regions were considered, organic matter showed a positive correlation with AM colonization. A similar trend was found for soil texture. Spore density was not correlated with soil $\mathrm{P}$ but seemed to be negatively influenced by $\mathrm{pH}$ considering all regions $(\mathrm{r}=-0.44)$. Coarse sand was positively correlated with spore density while clay showed a similar tendency when only West of Bahia was considered (Table 3). Silt showed no correlation with spore number.

Spore production in the trap cultures was frequent and abundant. Twenty four AM fungal species, representing all five families and seven genera, were identified in the papaya soil samples (Table 4). Glomus etunicatum and Acaulospora scrobiculata were the most frequent species, being present in more than $50 \%$ of the samples, followed by Paraglomus occultum and Gigaspora sp. with $45 \%$ and $41 \%$ of frequency, respectively. Most species were detected in less than $20 \%$ of the samples (Table 4). Some occurred exclusively in one region, like $G$. intraradices and $P$. brasilianum in the North of Espirito Santo and A. dilatata, A. longula and Scutellospora persica in the South of Bahia, though with very low occurrence index. At the genus level, Paraglomus, Entrophospora and Gigaspora were detected in all regions, being represented by one or two species each, while Archaeospora was not retrieved from North of Espirito Santo only. Glomus and Acaulospora were also detected in North of Espirito Santo and West of Bahia, and the latter outnumbered the former in South of Bahia (Table 4).

Total number of AM fungi species identified was fairly constant, although sampling in the South of Bahia had been more intensive (Table 5). North of Espirito Santo and South of Bahia had species richness values of 5.07 and 4.44, respectively, although both regions had larger and equivalent repetition indices. Papaya plantations of more than 2 years of age showed the lowest species richness (3.89). This characteristic tended to be higher in soils with $\mathrm{pH}>5.5$ and $\mathrm{P}$ levels $<50 \mathrm{mg} / \mathrm{dm}^{3}$ (Table 6). A. mellea, A. morrowiae, and E. colombiana were more frequent in soils with $\mathrm{pH}$ lower than 5.5, while $A$. scrobiculata and A. delicata were more frequent in soils with $\mathrm{pH}$ above 5.5 (Table 6). Glomus species also showed marked differences in their frequencies as a function of soil $\mathrm{pH}$. For instance, G. etunicatum occurred more at $\mathrm{pH}>5.5$ while $G$. intraradices and $G$. macrocarpum reached their highest frequencies at $\mathrm{pH}<5.5$. Distribution of Gigaspora sp. seemed to be related to soil $\mathrm{pH}$, since occurrence in soils with $\mathrm{pH}$ above 5.5 was three times higher than that in soils with $\mathrm{pH} \leq 5.5$. Some species, like Acaulospora sp., $G$. etunicatum and G. macrocarpum, showed almost the same
Table 4. Arbuscular mycorrhizal fungi species identified in soil samples from papaya (Carica papaya L.) fields and respective occurrence index for each region, based on spores recovered from trap culture with Sorghum bicolor (L.) Moench and Crotalaria juncea L.

\begin{tabular}{|c|c|c|c|}
\hline & $\begin{array}{l}\text { North of } \\
\text { Espírito Santo }\end{array}$ & $\begin{array}{l}\text { West of } \\
\text { Bahia }\end{array}$ & $\begin{array}{l}\text { South of } \\
\text { Bahia }\end{array}$ \\
\hline Fungal taxon & \multicolumn{3}{|c|}{ Ocurrence index $(\%)^{*}$} \\
\hline \multicolumn{4}{|l|}{ Acaulosporaceae } \\
\hline A. delicata, Walker, Pfeiffer \& Bloss & 26.7 & 12.5 & 22.2 \\
\hline A. dilatata, Morton & 0.0 & 0.0 & 3.7 \\
\hline A. longula, Spain \& Schenck & 0.0 & 0.0 & 11.1 \\
\hline A. mellea, Spain \& Schenck & 33.3 & 6.3 & 33.3 \\
\hline A. morrowiae, Spain \& Schenck & 33.3 & 0.0 & 11.1 \\
\hline A. rugosa, Morton & 26.7 & 12.5 & 0.0 \\
\hline A. scrobiculata, Trappe & 18.9 & 50.0 & 66.7 \\
\hline Acaulospora sp. & 6.7 & 25.0 & 11.1 \\
\hline E. colombiana, Spain \& Schenck & 6.7 & 12.5 & 22.2 \\
\hline Entrophospora sp. & 0.0 & 6.3 & 7.4 \\
\hline \multicolumn{4}{|l|}{ Archaeosporaceae } \\
\hline $\begin{array}{c}\text { Archaeospora trappei, } \\
\text { Ames \& Linderman }\end{array}$ & 0.0 & 6.3 & 7.4 \\
\hline \multicolumn{4}{|l|}{ Paraglomaceae } \\
\hline $\begin{array}{l}\text { Paraglomus brasilianum, } \\
\text { Spain \& Miranda }\end{array}$ & 6.7 & 0.0 & 0.0 \\
\hline Paraglomus occultum, Walker & 73.3 & 25.0 & 37.0 \\
\hline \multicolumn{4}{|l|}{ Glomaceae } \\
\hline G. etunicatum, Becker \& Gerdemann & 73.3 & 43.8 & 63.0 \\
\hline G. intraradices, Schenck \& Smith & 26.7 & 0.0 & 0.0 \\
\hline G. macrocarpum, Tulasne \& Tulasne & 33.3 & 25.0 & 11.1 \\
\hline G. mosseae, Gerdemann \& Trappe & 13.3 & 12.5 & 0.0 \\
\hline G. tortuosum, Schenck \& Smith & 13.3 & 6.3 & 0.0 \\
\hline Glomus sp. & 13.3 & 6.3 & 0.0 \\
\hline \multicolumn{4}{|l|}{ Gigasporaceae } \\
\hline Gigaspora sp & 13.3 & 68.8 & 40.7 \\
\hline S. cerradensis, Spain \& Miranda & 0.0 & 6.3 & 7.4 \\
\hline S. heterogama, Walker \& Sanders & 6.7 & 12.5 & 0.0 \\
\hline S. pellucida, Walker \& Sanders & 6.7 & 12.5 & 48.1 \\
\hline S. persica, Walder \& Sanders & 0.0 & 0.0 & 7.4 \\
\hline
\end{tabular}

* Percentage of soil samples, in each region, containing the respective specie.

frequency, regardless the P levels (Table 6). Other species, however, seemed to be less frequent at higher P levels, like $S$. pellucida which had its frequency reduced from $36.4 \%$ at $\mathrm{P}<50$ $\mathrm{mg} / \mathrm{dm}^{3}$ to $16.7 \%$ at $\mathrm{P}>100 \mathrm{mg} / \mathrm{dm}^{3}$. A similar trend was observed 
for A. delicata and A. scrobiculata. Availability of soil $\mathrm{P}$ seemed to be very selective for other species. For example, S. persica, S. heterogama and Archaeospora trappei were detected only in soil with 50 to $100 \mathrm{mg} / \mathrm{dm}^{3}$ of $\mathrm{P}$, while Paraglomus brasilianum occurred only in samples with $P$ levels below that range (Table 6).

\section{DISCUSSION}

Papaya showed a high diversity of AM fungi in its rhizosphere under field conditions. Species richness was related to soil available phosphorus. Considering that AM fungi are important components of the soil biota in sustainable cropping systems (3), maintaining high $\mathrm{P}$ levels as required by a productive papaya crop and low soil $\mathrm{pH}$, may inhibit $\mathrm{AM}$ colonization and adversely affect AM fungi. This may hamper crop sustainability, since it becomes more dependent on exogenous supply of nutrients and more susceptible to stressful conditions. Papaya soils may contain as much as $352 \mathrm{mg} / \mathrm{dm}^{3}$ of $P$ that shows negative correlation with AM root colonization (Table 3).

Finding a correlation between soil physical and chemical properties with AM colonization and spore density was a difficult task and depended on the region sampled (Table 3). Low AM colonization rate and spore density in samples from west of Bahia might be related, partially, to the high content of fine sand and low content of soil organic matter (Table 1). Fine sand contributes to soil pore occlusion and surface crust formation (2) which is known to influence fine root development and, consequently, AM colonization and sporulation. Low AM colonization and spore density in the West of Bahia crops suggest a low inoculum potential in these fields, associated with reduced root production. This may contribute to a cropping system with dependence on chemical fertilizers. As soil physical and chemical characteristics showed varied correlation with root colonization and spore density, other soil and plant characteristics have to be considered like crop age, which was positively correlated with AM colonization in South of Bahia. Saggin Júnior and Siqueira (20), studying the ocurrence of AM fungi in coffee fields, suggested that mycorrhizal colonization is more dependent on AM fungal population differences and respective inoculum potencial than on soil physical-chemical properties.

Results obtained from nursery plants indicated that the management practices adopted for seedlings production are not conducive to AM formation. This is probably due to the use of subsoil, fumigated
Table 5. Number of samples evaluated, total number of species, richness (average species number in a sample) and repetition index of arbuscular mycorrhizal fungi in soils cultivated with papaya (Carica papaya L.) in three regions in Brazil.

\begin{tabular}{lcccc}
\hline & $\begin{array}{c}\text { North of } \\
\text { Espírito Santo }\end{array}$ & $\begin{array}{c}\text { West of } \\
\text { Bahia }\end{array}$ & $\begin{array}{c}\text { South of } \\
\text { Bahia }\end{array}$ & TOTAL \\
\hline Number of samples & 15 & 16 & 27 & 58 \\
Number of species (a) & 18 & 18 & 17 & 24 \\
Richness (b) & 5.07 & 3.33 & 4.44 & 4.29 \\
Repetition index (b/a) & 0.28 & 0.19 & 0.26 & 0.18 \\
\hline
\end{tabular}

Table 6. Frequency, number and richness of arbuscular mycorrhizal fungi species in papaya (Carica papaya L.) fields with different classes of $\mathrm{pH}$ values and available soil $\mathrm{P}$, considering three regions in Brazil.

\begin{tabular}{|c|c|c|c|c|c|}
\hline & \multicolumn{5}{|c|}{ Classes of values } \\
\hline & \multicolumn{2}{|c|}{$\mathrm{pH}$} & \multicolumn{3}{|c|}{ Soil P $\left(\mathrm{mg} \mathrm{dm}^{-3}\right)$} \\
\hline & $\begin{array}{c}\leq 5.5 \\
\left(\mathrm{n}^{\circ}=23\right)\end{array}$ & $\begin{array}{c}>5.5 \\
\left(\mathrm{n}^{\mathrm{o}}=35\right)\end{array}$ & $\begin{array}{c}<50 \\
\left(n^{\circ}=22\right)\end{array}$ & $\begin{array}{l}50-100 \\
\left(n^{\circ}=18\right)\end{array}$ & $\begin{array}{c}>100 \\
\left(n^{\circ}=18\right)\end{array}$ \\
\hline Species number & 22 & 23 & 19 & 21 & 17 \\
\hline Richness & 3.5 & 4.4 & 4.6 & 4.4 & 3.4 \\
\hline Species identified & \multicolumn{2}{|c|}{ Frequency (\%) } & \multicolumn{3}{|c|}{ Frequency (\%) } \\
\hline A. delicata & 13.0 & 25.4 & 27.3 & 22.2 & 11.1 \\
\hline A. dilatata & 0.0 & 2.9 & 0.0 & 0.0 & 5.6 \\
\hline A. longula & 4.3 & 2.9 & 9.1 & 5.6 & 0.0 \\
\hline A. mellea & 39.1 & 19.5 & 36.4 & 22.2 & 22.2 \\
\hline A. morrowiae & 21.7 & 9.8 & 13.6 & 22.2 & 5.6 \\
\hline A. rugosa & 4.3 & 14.3 & 9.1 & 11.1 & 11.1 \\
\hline A. scrobiculata & 30.4 & 65.7 & 72.8 & 50.0 & 38.9 \\
\hline Acaulospora sp. & 13.0 & 20.0 & 18.2 & 16.7 & 22.2 \\
\hline E. colombiana & 21.7 & 8.6 & 18.2 & 5.6 & 16.7 \\
\hline Entrophospora sp. & 8.7 & 11.4 & 18.2 & 0.0 & 11.1 \\
\hline Archaeospora trappei & 4.3 & 5.6 & 0.0 & 16.7 & 0.0 \\
\hline P. brasilianum & 4.3 & 0.0 & 4.6 & 0.0 & 0.0 \\
\hline P. occultum & 34.8 & 51.5 & 50.0 & 55.6 & 33.3 \\
\hline G. etunicatum & 43.5 & 68.5 & 59.1 & 61.1 & 61.1 \\
\hline G. intraradices & 13.0 & 2.9 & 4.6 & 5.6 & 11.1 \\
\hline G. macrocarpum & 26.1 & 17.2 & 18.2 & 22.2 & 22.2 \\
\hline G. mosseae & 4.3 & 8.6 & 4.6 & 16.7 & 0.0 \\
\hline G. tortuosum & 4.3 & 2.9 & 0.0 & 5.6 & 5.6 \\
\hline Glomus sp. & 4.3 & 5.6 & 4.6 & 5.6 & 5.6 \\
\hline Gigaspora sp. & 17.4 & 54.3 & 50.0 & 38.9 & 38.9 \\
\hline S. cerradensis & 4.3 & 5.6 & 4.6 & 11.1 & 0.0 \\
\hline S. heterogama & 8.7 & 2.9 & 0.0 & 11.1 & 0.0 \\
\hline S. pellucida & 21.7 & 28.6 & 36.4 & 27.8 & 16.7 \\
\hline S. persica & 0.0 & 5.6 & 0.0 & 11.1 & 0.0 \\
\hline
\end{tabular}


substrate and a high fertility regime as the result of high levels of manure and soluble minerals. Similar findings have been reported in nursery-produced coffee outplants in Brazil (25). But when nursery plants are grown directly in the soil, like some citrus systems, root may appear highly colonized (26). It was showed that nursery substrates mixed with more than $10 \%$ of cow manure reduce AM colonization in papaya seedlings (28). The reduced AM formation at nursery stage is consistent with low AM colonization in the early cropping stage in many papaya fields. This may compromise initial development, with consequences for further crop performance.

The intensive sampling on papaya plantations, which represent a monoculture, revealed a high diversity at family and species levels, with all Glomeromycota families being represented and 24 species identified after trapping culture on native soil samples. Papaya mycorhizosphere richness is lower than that found (total of 36 species) in coffee plantations in the south of Minas Gerais (6) but much higher than that found (10 species) in citrus plantations in Bahia and Sergipe (30). Trapping the native soil with suitable hosts and assessment of sporulating species after 3-4 months allows the recovery of cryptic species, which may not be sporulating in the field (15).

A. scrobiculata showed high occurrence in the study, confirming its extensive distribution in tropical environments $(4,24,30)$. The high occurrence of Gigaspora sp. in West of Bahia plantations may reflect its tendency to be part of the Cerrado's bioclimatic region, which have shown high incidence of this genus (24). Alternatively, it may reflects low soil organic matter content as observed by Porter et al. (18) and also, soils with $\mathrm{pH}$ higher than 5.5 (23). Low soil $\mathrm{pH}$ influenced the occurrence of A. mellea and A. morrowiae, which corroborates other findings regarding the occurrence of these species in highly weathered soils $(24,30)$.

By analyzing the community structure of AM fungi associated with papaya plantations, it was observed that it tended to be dominated by few species, approaching the log series of the abundance model that describes situations where only few factors are controlling the whole community structure (13). In the papaya agrosystem, soil $\mathrm{pH}$ and available $\mathrm{P}$ are, probably, the main environmental factors determining species occurrence.

A high heterogeneity of species distribution is reflected as a small repetition index, such as found in the West of Bahia, indicating that species are more randomly distributed at that region. Species richness tended to become low in plantations older than 1 year, similarly to what was observed by Sieverding (23) in a monoculture of cassava, and by Siqueira et al. (24) studying the shift from native "Cerrado" to agrosystems. Cuenca and Menezes (4) did not observed a reduction of species diversity on cacao plantations and they attributed their results to the simultaneous growth of shadow plants in that system. It has been demonstrated that a short period of growth of different species of plant may change AM fungi diversity, demonstrating the existence of a selection pressure of plants on AM fungal communities (8).

The present study, associated with other finding showing a high response of papaya to AM fungi colonization, may indicate that papaya cropping in Brazil, seems to be highly dependent on chemical fertilization. The reasons could be the extremely low levels of mycorrhizal colonization on nursery papaya seedlings, the highly variable levels of mycorrhizal colonization in the field, the high levels of phosphate in the soil and the tendency to reduce AM fungi species richness over the plantation years and with the use of $P$ fertilization. On the other hand, the rich community of AM fungi associated with papaya found in this study and the results of Trindade et al. (27), demonstrate that inoculation with selected fungal isolates under nursery conditions is a reasonable approach towards sustainability. Besides, this community coud be managed by less disturbing soil practices such as reduced phosphorus fertilization and use of intercrops.

\section{RESUMO}

\section{Fungos micorrízicos arbusculares em pomares de mamoeiro do Espírito Santo e Bahia no Brasil}

O trabalho objetivou a obtenção de conhecimento sobre a associação micorrízica arbuscular (MA) em mamoeiro (Carica papaya, L.) em condições de pomar e viveiro. Sessenta e sete amostras de solo e raízes foram coletadas em quarenta e sete pomares comerciais nos meses de fevereiro e maio de 1996, abrangendo o Norte do Espírito Santo e o Oeste e Sul da Bahia. Amostras foram usadas para contagem direta de esporos, avaliação da colonização radicular e para cultivo armadilha com Sorghum bicolor (L.) Moench e Crotalaria juncea (L.). Amostragens adicionais foram feitas em viveiros comerciais, para avaliar a colonização micorrízica. Embora os sistemas de cultivo do mamoeiro recebam grande quantidade de insumos na forma de fertilizantes e pesticidas, as raízes apresentaram percentagem de colonização radicular variando de $6 \%$ a $83 \%$. As taxas de colonização mostraram-se relacionadas com o P disponível do solo, correlacionando-se positivamente com areia e pH do solo, mas negativamente com os teores de argila. Em viveiros, a percentagem de colonização nas plântulas foi baixa na maioria das amostras. Em campo o número de esporos variou de 34 a 444/30g de solo. Todas as famílias do filo Glomeromycota estiveram representadas e 24 espécies fúngicas foram identificadas. Glomus etunicatum, Paraglomus occultum, Acaulospora scrobiculata e Gigaspora sp. foram as espécies de maior ocorrência.

Palavras-chave: Glomeromycota, agroecossistemas, ecologia, Carica papaya 


\section{REFERENCES}

1. Ambler, J.R.; Young, J.L. Techniques for determining root length infected by vesicular-arbuscular mycorrhizae. Soil Sci. Soc. Am. J., 4, 551-556, 1977.

2. Baver, G.R.; Gardner, W.H.; Gardner, W.R. Soil physics. 4. ed. Jonh Wiley \& Sons, New York, 1972, 498 pp.

3. Bethlenfalvay, G.J.; Barea, J.M. Mycorrhizae in sustainable agriculture. I. Effects on seed yield and soil aggregation. Am. J. Alter. Agric., 9, 157-161, 1994.

4. Cuenca, G.; Meneses, E. Diversity patterns of arbuscular mycorrhizal fungi associated with cacao in Venezuela. Pl. Soil, 183, 315-322, 1996.

5. Edwards, A.L. The Correlation Coefficient. In: Freeman, W.H. An Introduction to Linear Regression and Correlation. San Francisco, 1976, pp.33-46.

6. Fernandes, A.B.; Siqueira, J.O. Micorrizas vesicular-arbusculares em cafeeiros da região sul do Estado de Minas Gerais. Pesq. Agropec. Bras., 24, 1489-1498, 1989.

7. Girija, V.K.; Nair, S.K. Incidence of VAM in banana varieties. Ind. $J$. Microbiol., 28, 294-295, 1989.

8. Gollote, A.; van Tuinen, D.; Atkinson, D. Diversity of arbuscular mycorrhizal fungi colonising roots of the grass species Agrostis capillaries and Lolium perenne in a field experiment. Mycorrhiza, 114, 111-117, 2004.

9. Instituto Brasileiro de Geografia e Estatística. IBGE. Banco de dados agregados - Produção Agrícola Municipal. Available at http:// www.sidra.ibge.gov.br/bda/agric (May, 2003).

10. International Culture Collection of (Vesicular) Arbuscular Mycorrhizal Fungi. Avalilable at: Site Invam. URL: http://invam.caf.wvu.edu (January, 2005).

11. International Culture Collection of (Vesicular) Arbuscular Mycorrhizal Fungi. Available at http://invam.caf.wvu.edu/fungi/taxonomy/ speciesID.htm (Fev-Mar, 1998).

12. Johnson, N.C.; Zak, D.R.; Tilman, D.; Pfleger, F.L. Dynamics of vesicular-arbuscular mycorrhizae during old field succession. Oecologia, 86, 349-358, 1991.

13. Magurran, A.E. Ecological diversity and its measurement. Princeton University Press, Princeton, 1988, 179 pp.

14. Mamatha, G.; Bagyaraj, D.J.; Jaganath, S. Inoculation of fieldestablished mulberry and papaya with arbuscular mycorrhizal fungi and a mycorrhiza helper bacterium. Mycorrhiza, 12, 313-316, 2002

15. Morton, J.B.; Bentivenga, S.P.; Bever, J.D. Discovery, measurement, and interpretation of diversity in arbuscular endomycorrhizal fungi (Glomales, Zygomycetes). Can. J. Bot., 73, 25-32, 1995

16. Nemec, S.; Menge, J.A.; Platt, R.G.; Johnson, E.L.V. Vesiculararbuscular mycorrhizal fungi associated with citrus in Florida and
California and notes on their distribution and ecology. Mycologia, 73(1), 112-127, 1981.

17. Phillips, J.M.; Hayman, D.S. Improved procedures for clearing roots and staining parasitic and vesicular-arbuscular mycorrhizal fungi for rapid assessment of infection. Trans. Br. Mycol. Soc., 55, 158-161, 1970.

18. Porter, W.M.; Robson, A.D.; Abbott, L.K. Field survey of the distribution of vesicular-arbuscular mycorrhizal fungi in relation to soil pH. J. Appl. Ecol., 24, 659-662, 1987.

19. Remy, W.; Taylor, T.N.; Hass, H.; Kerp, H. Four hundred million year old vesicular arbuscular mycorrhizae. Proc. Nat. Acad. Sci. USA, 91, 11841-11843, 1994.

20. Saggin Jr., O.J.; Siqueira, J.O. Micorrizas arbusculares em cafeeiro. In. Siqueira, J.O. (Ed.). Avanços em fundamentos e aplicação de micorrizas. Universidade Federal de Lavras, Lavras, 1996, pp.203-254.

21. Schenck, N.C.; Pérez, Y. Manual for the identification of VA mycorrhizal fungi. 2. ed. Synergistic, Gainesville, 1987, 241 pp.

22. Schußler, A.; Schwarzott, D. Walker, C. A new fungal phylum, the Glomeromycota: phylogeny and evolution. Mycol. Res., 102, 14131421,2001

23. Sieverding, E. Vesicular-Arbuscular Mycorrhiza management in tropical agrosystems. Deutsche Gesellschaft fur Technische Zusammenarbeit, Eschborn, 1991, 371 pp.

24. Siqueira, J.O.; Colozzi-Filho, A.; Oliveira, E. Ocorrência de micorrizas vesicular-arbusculares em agro e ecossistemas do Estado de Minas Gerais. Brasília, Pesq. Agropec. Bras., 24, 1499-1506, 1989.

25. Siqueira, J.O.; Colozzi-Filho, A.; Oliveira, E.; Fernandes, A.B. Florence, M.L. Micorrizas vesicular-arbusculares em mudas de cafeeiro produzidas no sul do Estado de Minas Gerais. Pesq. Agropec. Bras., 22, 31-38, 1987.

26. Souza, P.V.D.; Schmitz, J.A.K.; Freitas, R.S.; Carniel, E.; Carrenho, R. Identificação e quantificação de fungos micorrízicos arbusculares autóctones em municípios produtores de citros no Rio Grande do Sul. Pesq. Agropec. Bras., 37, 555-558, 2002.

27. Trindade, A.V.; Farias, N.G.; Almeida, F.P. Adequação do uso de esterco na obtenção de mudas de mamão (Carica papaya L.) inoculadas com fungos micorrízicos arbusculares. Brasília, Pesq. Agrop. Bras., 35, 1389-1394, 2000.

28. Trindade, A.V.; Siqueira, J.O.; Almeida, F.P. Eficiência simbiótica de fungos micorrízicos arbusculares em solo não fumigado, para mamoeiro. R. Bras. Ci. Solo, 24, 479-692, 2000.

29. Weber, O.; Amorim, S.M.C. Adubação fosfática e inoculação de fungos micorrízicos vesículo-arbusculares em mamoeiro "solo". R. Bras. Ci. Solo, 18, 187-191, 1994.

30. Weber, O.B.; Oliveira, E. Ocorrência de fungos micorrízicos vesículoarbusculares em citros nos estados da Bahia e Sergipe. Pesq. Agropec. Bras., 29, 1905-1914, 1994. 